\title{
ANODIC ELECTROLYTIC DISSOLUTION OF COPPER SULPHIDES PRECIPITATED FROM AMMONIACAL LEACHING MEDIA
}

\author{
ALEJANDRO MORALES (1), JOSÉ FCO. HEVIA (2); DOMINGO SANTIS (1), GERARDO CIFUENTES (3).
}

\author{
(1) Departamento de Ingeniería Metalúrgica, Universidad Católica del Norte. \\ (2) Departamento de Química, Universidad Católica del Norte. \\ Avenida Angamos 0610, Antofagasta, Chile. \\ (3) Departamento de Ingeniería Metalúrgica, Universidad de Santiago de Chile. \\ Avda. L. B. O'Higgins 3363, Santiago, Chile
}

(Received: July 8, 2008 - Accepted: September 3, 2008)

\begin{abstract}
Anodic dissolution of synthetic chalcocite (previously obtained by copper precipitation with $\mathrm{S}$ and $\mathrm{SO}_{2}$ in ammonia media) in two different electrolytic cells is described. One cell has a circular graphite anode placed horizontally, surrounded by a stainless steel cylinder as cathode, and the other has a rectangular basketshaped graphite anode, with a rectangular stainless steel cathode placed in front of it.

The electrolysis was performed at $0.2 \mathrm{~A}$ and $50{ }^{\circ} \mathrm{C}$, the electrolyte contained 20 to $40 \mathrm{~g} \mathrm{~L}^{-1}$ of Cu and 100 to $160 \mathrm{~g} \mathrm{~L}^{-1}$ of $\mathrm{H}_{2} \mathrm{SO}_{4}$, and the initial reactions took place at low potential $(0.4-0.6 \mathrm{~V})$ until the transformation of $\mathrm{Cu}_{2} \mathrm{~S}$ into $\mathrm{CuS}$, detected by the considerable increase in cell potential. Anodic and cathodic efficiencies greater than $100 \%$ and $95 \%$, respectively, were obtained. The hight anodic efficiencie is due to faradic and chemical dissolution too. It is also shown that the (CuS) produced as waste material can replace elemental sulphur as copper precipitating agent in ammoniacal media.
\end{abstract}

Keywords: Copper, anodic dissolution, copper sulphide, anodic graphite.

\section{INTRODUCTION}

\section{Anodic dissolution.}

Anodic dissolution of copper sulfides (such as copper concentrates or matte) is not a new idea. In 1882 Marchese $^{1}$ tried to apply this method to concentrates with low copper content, but problems with the cell's high tension, contamination of the solution with iron during electrolysis, and the bad quality of the cathodic deposit made him give up. New methods and techniques were developed in this field, such as the use of white metal anodes instead of concentrates, but the processes were not commercialized.

Habashi and Torres-Acuña ${ }^{6}$ used white metal anodes, mainly of $\mathrm{Cu}_{2} \mathrm{~S}$, obtained by melting copper concentrates. They used sulfuric acid and cupric sulfate as electrolyte in the anodic dissolution and a copper sheet as cathode. At the end of the experiment, the composition of the solid residues was $80 \%$ elemental sulfur and $20 \% \mathrm{CuS}$, and the efficiency of the cathodic current was 98\%. They proposed three stages for the anodic dissolution: first, conversion of $\mathrm{Cu}_{2} \mathrm{~S}$ to $\mathrm{Cu}_{198} \mathrm{~S}$, followed by the formation of $\mathrm{CuS}$, and finally dissolution as $\mathrm{Cu}^{2+}$ ions and formation of elemental sulfur (when working with low current density). The cathodic deposit obtained was comparable to that in conventional electrolytic refining.

Brennet et al. ${ }^{7}$ worked under galvanostatic and potentiostatic conditions using compressed $\mathrm{Cu}_{2} \mathrm{~S}$ powder as anode, and the anodic solution contained sulfuric acid. They found that current density increases rapidly at first, reaches a maximum, and then decreases, but never drops to zero. By $\mathrm{X}$-ray diffraction they detected the existence of digenite $\left(\mathrm{Cu}_{18} \mathrm{~S}\right)$ during the early current density increase, then blue covelline $\left(\mathrm{Cu}_{1.1} \mathrm{~S}\right)$ appears when the current density decreases (depending on the anodic potential, because at high potential there is sufficient energy for nucleation of covelline - CuS), and finally dissolution as $\mathrm{Cu}^{2+}$ ions and elemental sulfur. The anodic potential also has an influence on the experiments because when it increases, the efficiency of the current decreases. Galvanostatic experiments were also made, with similar results in the anodic dissolution.

Anodic dissolution of $\mathrm{Cu}_{2} \mathrm{~S}$ was also studied by D.J. Mackinnon ${ }^{8}$ by the fluidized bed technique, which consists in allowing the electrolyte pulp and particles of $\mathrm{Cu}_{2} \mathrm{~S}$ to flow over an inert platinum anode, with the advantage that the anodic surface of this sulfide is larger per unit volume compared to conventional flat electrodes, because the sulfide is in powder form. When $\mathrm{H}_{2} \mathrm{SO}_{4}$ was used as electrolyte, $50 \%$ of the copper present in the sulfide was extracted, and later oxygen evolution was seen at the platinum anode.

Mackinnon found that the anodic dissolution using this technique took place in two stages: the first corresponds to the oxidation of $\mathrm{Cu}_{2} \mathrm{~S}$ to $\mathrm{Cu}_{11} \mathrm{~S}$, and the second, which was detected due to the increase of the cell potential, corresponds to the dissolution of $\mathrm{Cu}_{11} \mathrm{~S}$ as cupric ions and to the formation of elemental sulfur when $\mathrm{H}_{2} \mathrm{SO}_{4}-\mathrm{NaCl}$ or $\mathrm{H}_{2} \mathrm{SO}_{4}-\mathrm{KBr}$ was used as electrolyte.

Habashi and Torres-Acuña ${ }^{6}$, working with white metal anodes, confirmed the dissolution mechanism mentioned above by analyzing the residues obtained from different parts of the surface of the anode. It was also established that at low current density these residues contain more $\mathrm{CuS}$ than at high current density.

Mackinnon $^{8}$, studying the intermediate products by X-ray diffraction and chemical analysis, showed that in the anodic dissolution of chalcocite $\left(\mathrm{Cu}_{2} \mathrm{~S}\right)$ under controlled current and potential conditions, and with a sulfuric acid electrolyte, the transformation is the following:

$$
\mathrm{Cu}_{2} \mathrm{~S} \rightarrow \mathrm{Cu}_{1.1} \mathrm{~S}+0.9 \mathrm{Cu}^{2+}+1.8 \mathrm{e} \text {. }
$$

Later, the anodic potential increases noticeably, with oxygen evolution at the platinum anode, working galvanostatically, and the dissolved copper decreases and then remains constant. With the potential controlled sufficiently low as to avoid the release of oxygen, the current decreases substantially and the reaction becomes very slow, a result similar to that obtained by Habashi ${ }^{6}$ and Brennet ${ }^{7}$.

Peters $^{9}$ confirmed the possibility of refining copper matte electrolytically from white metal if the latter is powdered, extracting $60 \%$ of the copper, and working with pure $\mathrm{Cu}_{2} \mathrm{~S}$ the extraction rises to $75 \%$ before anodic polarization occurs.

The anodic dissolution mechanism of $\mathrm{Cu}_{2} \mathrm{~S}$ is not as simple as shown by the authors mentioned above, because the reaction is more complex. Vitorge and Lamache ${ }^{10}$, who dissolved $\mathrm{CuS}_{2}$ anodically, found $\mathrm{Cu}_{192} \mathrm{~S}, \mathrm{Cu}_{177} \mathrm{~S}, \mathrm{Cu}_{160} \mathrm{~S}$ and $\mathrm{Cu}_{131} \mathrm{~S}$. Srinivasan et al. ${ }^{11}$ showed that the electrochemical behavior and the products of the dissolution will depend not only on the conditions of the process, but also on the origin of the copper sulfide. However, it can be accepted that this takes place in two successive steps, with the tension in the cells increasing to $0.6 \mathrm{~V}$ in the first step and to $1.6 \mathrm{~V}$ in the second:

$$
\begin{aligned}
& \mathrm{Cu}_{2} \mathrm{~S}_{(\mathrm{s})} \rightarrow \mathrm{CuS}_{(\mathrm{s})}+\mathrm{Cu}^{2+}+2 \mathrm{e}^{-} \\
& \mathrm{CuS}_{(\mathrm{s})} \rightarrow \mathrm{S}+\mathrm{Cu}^{2+}+2 \mathrm{e}^{-}
\end{aligned}
$$

Guzmán et al. $^{12}$ proposed a method for obtaining electrolytic copper from copper concentrate through the following steps: sulfating roasting of copper concentrates at $700{ }^{\circ} \mathrm{C}$; two leaching steps of the calcines at ambient temperature (in alkaline and acid media) with total recovery of copper in solution higher than $95 \%$; precipitation of copper sulfide from the leaching solution with sulfur and sulfur dioxide; and finally, at the same time, anodic dissolution of the copper sulfide to obtain the copper at the cathode. 
Hevia et al. ${ }^{13,14,15}$ have studied the precipitation of $\mathrm{Cu}$ with $\mathrm{SO}_{2}$ and $\mathrm{S}$ in ammoniacal solutions at alkaline $\mathrm{pH}$, achieving better than $90 \% \mathrm{Cu}$ precipitation at ambient temperature. The overall reaction for precipitation in an ammoniacal environment is:

$2 \mathrm{Cu}\left(\mathrm{NH}_{3}\right)_{4}{ }^{2+}{ }_{\text {(aq) }}+2 \mathrm{SO}_{2(\mathrm{~g})}+\mathrm{S}_{(\mathrm{s})}+4 \mathrm{H}_{2} \mathrm{O}=>\mathrm{Cu}_{2} \mathrm{~S}_{(\mathrm{s})}+8 \mathrm{NH}_{4 \text { (aq) }}^{+}+2 \mathrm{SO}_{4 \text { (aq) }}^{2-}$

In the above equation it is possible to replace $\mathrm{S}$ by a copper sulfide material of the CuS type:

$\mathrm{Cu}\left(\mathrm{NH}_{3}\right)_{4}{ }_{4(\mathrm{aq})}^{2+}+\mathrm{SO}_{2(\mathrm{~g})}+\mathrm{CuS}_{(\mathrm{s})}+2 \mathrm{H}_{2} \mathrm{O}=>\mathrm{Cu}_{2} \mathrm{~S}_{(\mathrm{s})}+4 \mathrm{NH}_{4 \text { (aq) }}^{+}+\mathrm{SO}_{4}^{2-}$ (aq)

\section{Methodology}

The purpose of this work was to determine the behavior of the sulfide $\left(\mathrm{Cu}_{2} \mathrm{~S}\right)$, previously obtained by precipitation in an ammoniacal medium, in an anodic dissolution process, to obtain electrolytic copper at the cathode and a covellite-type residue at the anode. Electrolytes of similar composition and at the same temperature as those used in electrolytic cells for electrodeposition of copper in industry were used for the present work.

The anode material was graphite, whose good performance from the standpoint of corrosion has been shown because of the lack of Fe in the electrolytic system due to the low anodic potential of the process, which prevents the evolution of $\mathrm{O}_{2}$ on the surface of the anode and the formation of $\mathrm{S}$ as an anodic residue. The anodic process continues until a covellitic residue $(\mathrm{CuS})$ is formed, in order to prevent the increase of the anodic potential and the formation of $\mathrm{S}$, since the latter is neither an electric conductor nor a semiconductor.

\section{Obtaining $\mathrm{Cu}_{2} \mathrm{~S}$}

A suficient quantity of $\mathrm{S}$ was added for a solution of $30 \mathrm{~g} \mathrm{~L}^{-1} \mathrm{Cu}, 2 \mathrm{M}$ total $\mathrm{NH}_{3}, \mathrm{pH}=9.0$, at ambient temperature, and excess $\mathrm{SO}_{2}$, until $80 \%$ of the copper precipitated. The precipitated sulfide containing $78.5 \% \mathrm{Cu}$, identified by X-ray diffraction, was mainly $\mathrm{Cu}_{197} \mathrm{~S}$ (djurleite), and it was used in this study.

The different ways of obtaining $\mathrm{Cu}_{2} \mathrm{~S}$ are specified in a previous publication ${ }^{16}$.

\section{Anodic dissolution.}

Solutions containing 100 and $160 \mathrm{~g} \mathrm{~L}^{-1}$ of sulfuric acid, and 20 and $40 \mathrm{~g} \mathrm{~L}^{-1}$ of copper at a temperature of $50{ }^{\circ} \mathrm{C}$ were used as electrolytes. The anode was graphite and the cathode was a stainless steel sheet and an $\mathrm{Ag} / \mathrm{AgCl}$ reference electrode. The copper sulfide in the precipitation (djurleite: $79.0 \% \mathrm{Cu}$ ) was introduced in the anode and the electrolysis was carried out under galvanostatic conditions, using a Hewlett Packard 6214-A power supply at a constant electric current intensity of $0.2 \mathrm{~A}$. Two types of cells were used: A cell with a horizontal graphite anode in which the anodic compartment is cylindrical and it has a PVC structure covered with a filtering polyethylene sheet (diaphragm), and the cathode is a stainless steel cylinder whose mantle surrounds the anode compartment. The other cell has a vertical basket-shaped graphite anode and its cathode is a stainless steel sheet placed in front of the basket at a distance of approximately $5 \mathrm{~mm}$.

Diagrams of these cells are shown in Figures 1 and 2:

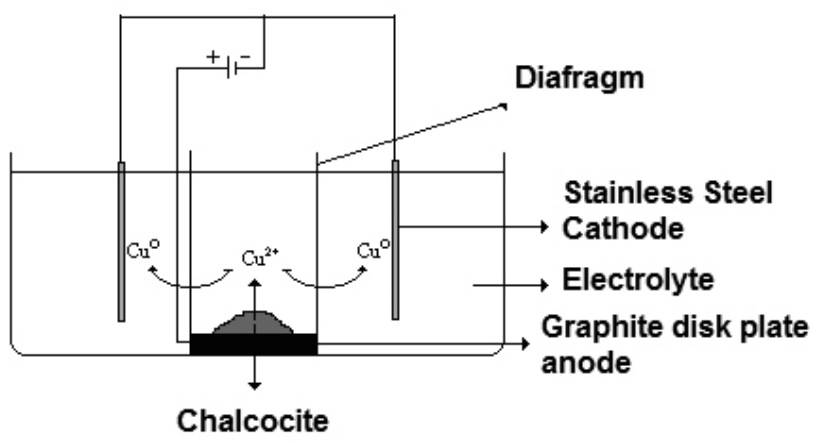

Figure 1.- Cell with circular graphite anode.

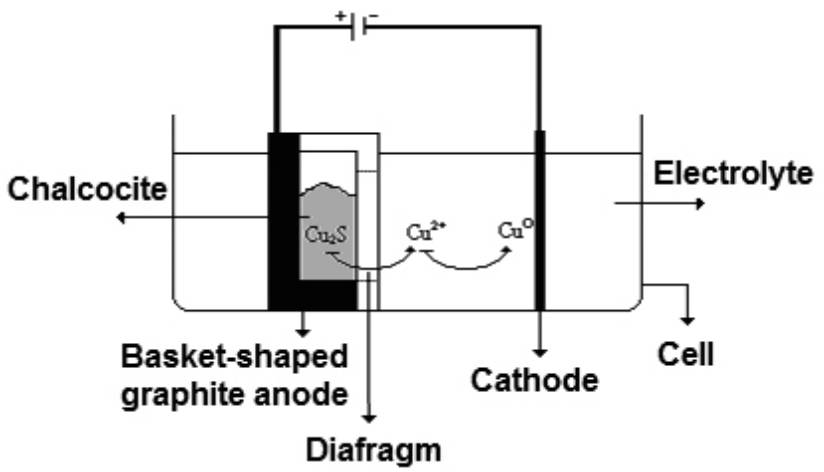

Figure 2.- Cell with basket-shaped graphite anode.

\section{RESULTS}

Anodic solution with cylindrical graphite anode.

Three tests were carried out with this system under the conditions described in Table I. The results of the anodic electrodissolution are shown in Figure 3.

In the tests of this cell the aim has been to observe the phenomenon of anodic electrodissolution up to the stage of $\mathrm{CuS}$ formation and see the effect of the mass of precipitate on electrolysis time for different acid and copper concentrations in the electrolyte.

Table I - Cell with circular graphite anode.

\begin{tabular}{|l|c|c|c|c|}
\hline \multicolumn{1}{|c|}{ Test } & & 1 & 2 & 3 \\
\hline Initial Cu concentration & $\mathrm{g} \cdot \mathrm{L}^{-1}$ & 40 & 20 & 20 \\
Initial acid concentration & $\mathrm{g} \cdot \mathrm{L}^{-1}$ & 160 & 100 & 100 \\
Mass of chalcocite & $\mathrm{g}$ & 2 & 5 & 14 \\
\hline
\end{tabular}

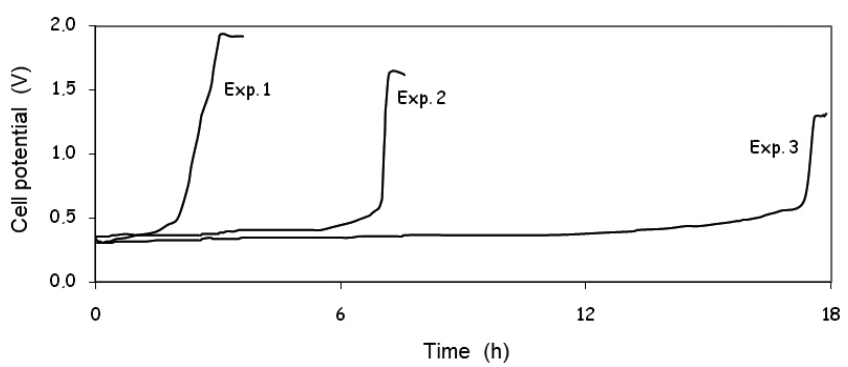

Figure 3.- Experiments with circular graphite anode. 


\section{Anodic dissolution with basket-shaped graphite anodes.}

The conditions of tests 4 and 5 are given in Table II; the difference between them is related to the way in which the basket was filled. In experiment 5 the chalcocite was compacted into the basket, while in experiment 4 it was not. Figure 4 illustrates these results.

In test 4 the basket was loaded by pouring the precipitate directly, and in the cell the electrolyte was poured slowly along the side of the basket. In test 5 the precipitate was poured directly into the basket, and the electrolyte was poured slowly over the precipitate in the basket, producing a compacting effect on the precipitate, whose height in the basket decreased $20 \%$.

Table II.- Cell with basket-shaped graphite anode (compaction effect)

\begin{tabular}{|l|c|c|c|}
\hline \multicolumn{1}{|c|}{ Test } & & 4 & 5 \\
\hline Cell volume & $\mathrm{mL}$ & 165 & 165 \\
Initial copper concentration & $\mathrm{g} \mathrm{L}^{-1}$ & 40 & 40 \\
Initial acid concentration & $\mathrm{g} \mathrm{L}^{-1}$ & 160 & 160 \\
Initial mass of chalcocite & $\mathrm{g}$ & 5 & 5 \\
\hline
\end{tabular}

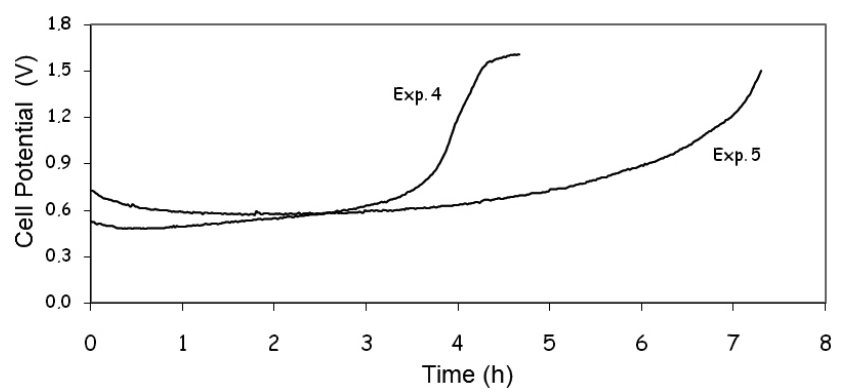

Figure 4.- Anodic electrodissolution experiments (compaction effect).

Table III gives the conditions of experiments 6 and 7, in addition to the previous experiment 5 (for comparison). These tests showed the effect of the quantity of chalcosine in the anode. Figure 5 illustrates these results.

Tests 6 and 7 were made in the same way as test 5 , disregarding the effect of compaction and showing the effect of mass, which gives rise to selfcompression.

Table III.- Cell with basket-shaped graphite anode (effect of amount)

\begin{tabular}{|l|c|c|c|c|}
\hline \multicolumn{1}{|c|}{ Test } & & 5 & 6 & 7 \\
\hline Cell volume & $\mathrm{mL}$ & 165 & 165 & 130 \\
Initial copper concentration & $\mathrm{g} \mathrm{L}^{-1}$ & 40 & 40 & 40 \\
Initial acid concentration & $\mathrm{g} \mathrm{L}^{-1}$ & 160 & 160 & 160 \\
Initial mass of chalcocite & $\mathrm{G}$ & 5 & 9 & 10 \\
\hline
\end{tabular}

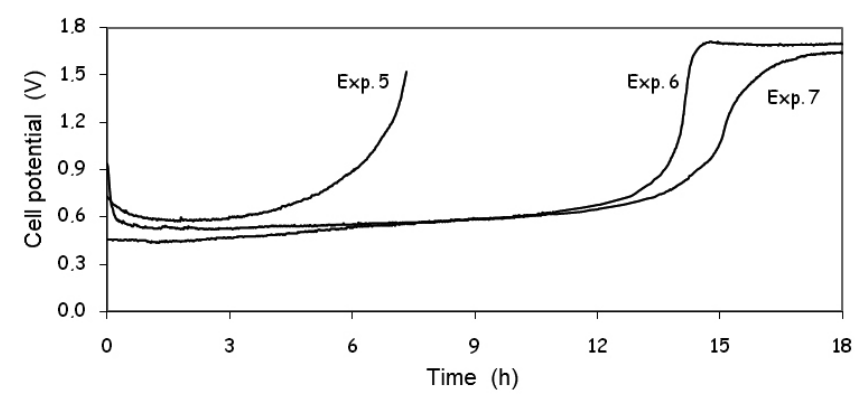

Figure 5.- Experiments with basket-shaped graphite anode (effect of mass).

Each anodic dissolution experiment was carried out until the cell potential increase due to the formation of $\mathrm{CuS}$ was detected; copper extraction varied between $48 \%$ and $50 \%$ and copper residues of $64 \%$ were obtained. Identification by X-ray diffraction indicated covelline $(\mathrm{CuS})$ as the main species, and no elemental S was detected. The efficiencies of the anodic and cathodic currents were approximately $112 \%$ and $98 \%$, respectively. The hight anodic efficiencie is due to faradic and chemical dissolution, both effects occur in parallel.

The performance of graphite as anodic material was as expected, and no corrosion or contamination of the cathodic $\mathrm{Cu}$ with $\mathrm{C}$ was detected. There was no evolution of oxygen at the anode, and neither was elemental sulfur formed, due to the control of electrolysis during the test.

The residue (of the CuS type) obtained from the anodic electrodissolution was reused to precipitate chalcocite $\left(\mathrm{Cu}_{2} \mathrm{~S}\right)$ in place of sulfur, a precipitation that is in agreement with Equation (5). Copper precipitation under these conditions is practically quantitative, and the final product corresponds to djurleite (identified by X-ray diffraction).

For example, the $59.1 \% \mathrm{Cu}$ residue, which was a polycrystalline solid -in which basically the covelline phase $(\mathrm{CuS})$ was identified by X-ray diffractiongenerated in the precipitation of copper in an ammoniacal environment, gave rise to a polycrystalline solid with $75.2 \% \mathrm{Cu}$ in which the djurleite $\left(\mathrm{Cu}_{198} \mathrm{~S}\right)$ and chalcocite (CuS) phases were identified by X-ray diffraction.

\section{DISCUSSION}

Figure 3, which corresponds to the experiments made with a circular graphite anode, shows a behavior of copper sulfide, obtained by the method of precipitation, similar to that described in the literature ${ }^{2,3,4,5}$ for the anodic electrodissolution of chalcocite, i.e., in the first stage the process is carried out at low cell potential $(0.4-0.6 \mathrm{~V})$ to obtain the $\mathrm{CuS}$ (Equation 2), and then that potential is increased considerably (up to $1.6 \mathrm{~V}$ ) to extract a larger amount of copper and get sulfur as final product, in agreement with Equation (3).

The rectangular cell, similar to the industrial design for the electrorefining of copper process, and the basket-shaped anode showed a behavior of the anodic dissolution similar to that of the cell with a circular anode. The only significant difference is that for the small amounts of chalcosine used a prior compression was required to obtain the extraction yields close to $50 \%$ before the increase of the cell's potential, as shown in Figure 4. However, when using larger amounts of chalcosine this procedure was not necessary due to the natural compression caused by the weight of the particles, which allows good contact between them. The anodic dissolution achieved extractions close to $50 \%$ at cell potentials lower than $0.6 \mathrm{~V}$, as shown in Figure 5.

The anodic current efficiency achieved before the cell potential increase, higher than $100 \%$, shows that together with anodic dissolution there is chemical dissolution.

The process of precipitation of chalcocitic sulfide prevents the presence of an agressive contaminant in the electrolysis, like the $\mathrm{Fe}$ and $\mathrm{Cl}$ present in the leaching solutions, in that way guaranteeing the life of the graphite anode in these electrodissolutions.

Controlling the process by means of the cell potential prevents the formation of S, so that the graphite does not become contaminated with that element.

In view of the characteristics of the process (which operates at low cell potential in order to reach the stage of formation of the covellitic residues), the working potential is about $0.6 \mathrm{~V}$, which prevents the evolution of $\mathrm{O}_{2}$ on the graphite surface and its corrosion.

In all the experiments a cathodic deposit was obtained on the steel sheet, well adhered and without nodules.

There were no positive results either when using basket-shaped anodes or materials such as lead, iron, and stainless steel for that same anode support function.

\section{CONCLUSIONS}

It has been shown that anodic electrodissolution of copper sulfide is possible by the proposed precipitation method and that its performance is similar to that of the anodic electrodissolution of other copper sulfides described in the literature.

The results obtained with the cell with a basket-shaped graphite anode were very encouraging as to consider its implementation at the level of an 
industrial process.

As expected, the residues (CuS type) of anodic electrodissolution can be used as agents for the precipitation of copper in an ammoniacal medium by replacing the sulfur.

This allows a proposal of a process for obtaining electrolytic copper from ammoniacal leaching solutions as shown in the following diagram:

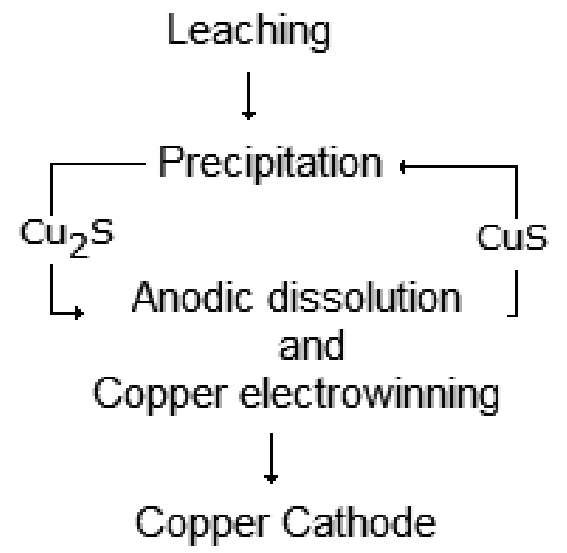

Figure 6.- Summary flow diagram.

The innovative characteristics of the stages of this process (anodic precipitation and dissolution) make this proposal a clean technology for copper production.

\section{BIBLIOGRAPHY}

1.- Hencyclopedia Britannica, $11^{\text {th }}$ Edition, 7,110,(1911).

2.- J. F. Hevia, T. Politis, Proc. of the IV National Congr. of Chem. Eng., Universidad de Concepción, Concepción, Chile (1977).

3.- F.A. Baczek et al., Process and Fundamentals Considerations of Selected Hydrometallurgical Systems. Society of Mining Engineers of AIME, 125, (1981).

4.- J. Llanos, C. Mujica, J. F. Hevia, Proceeding of the II Meeting of Inorganic Chem., Universidad de Chile, Santiago, Chile, (1986).

5.- J. F. Hevia, C. Mujica, T. Politis, J. Llanos, V. Den Braver, Chilean Patent No. 41607, (2002).

6.- F. Habashi, N. Torres-Acuna, Trans. of the Metall. Soc. of AIME. 242, 782 (1968).

7.- P. Brennet, P. S. Jafferali et al., Metallurgical Trans., 5, 127 (1974).

8.- D.J. Mackinnon, Hydrometallurgy, 1, 242 (1976).

9.- M.H. Mao and E. Peters, Can. Metall. Q., 22, No. 4, 437 (1983).

10.- P.Vitorge et M. Lamarche, Electrochimica Acta, 24, 811 (1979).

11.- V. Srinavasan, R.S. Parikh and K.C. Liddell, Metall. Trans. B., 23B, 879, (1992).

12.- M. Guzmán, J.F.Hevia, Proc. of the IX Inter. Congr. of Extractive Metallurgy. Universidad de Sonora, Sonora, México, (1999).

13.- Hevia, J.F., Politis, T., Symp. of Chem. and National Develop., Sociedad Chilena de Química, Concepción, Chile, 34, (1985).

14.- Hevia, J.F., Mujica. C., Politis, T., Llanos, J., der Braven, V., Chilean Patent, No. 41.607, (2002).

15.- Hevia, J.F., II Encuentro Minero del Cono Sur de América, Iquique, Chile, Agosto, (2001).

16.- Morales J. F. Hevia, G. Cifuentes., Rev. de Metalurgia, Madrid, España, en prensa, (2009) 